\title{
PERANCANGAN APLIKASI PENGADUAN MASYARAKAT TERHADAP LINGKUNGAN DI TINGKAT KELURAHAN
}

\author{
Imam Syafei $^{1)}$,Mia Kamayani ${ }^{2)}$, Estu Sinduningrum ${ }^{3)}$ \\ ${ }^{1), 2), 3)}$ Program Studi Teknik Informatika Fakultas Teknik, \\ Universitas Muhammadiyah Prof. Dr. HAMKA, \\ Jalan Tanah Merdeka No. 6 B Kp. Rambutan Jakarta Timur 13830 \\ Telepon: 8400941, 87782739, E-mail: syafei144@ gmail.com, mia.kamayani@uhamka.ac.id, \\ estu.ningrum@uhamka.ac.id \\ Mobile: 087782320176
}

\begin{abstract}
Abstrak - Aplikasi pengaduan masyarakat adalah sebuah sarana aspirasi dalam bentuk pengaduan masyarakat berbasis online yang berprinsip mudah, terpadu dan tuntas untuk pengawasan lingkungan. Penelitian ini bertujuan untuk membuat suatu aplikasi yang bisa dipakai memudahkan masyarakat untuk melaporkan suatu kejadian dan bisa direspon atau ditanggapi dengan cepat, efektif dan efesien oleh pihak instansi terkait. Dengan mengunakan metode pengembangan sistem Extreme Programming (XP) diharapkan aplikasi yang dibuat lebih cepat selesai dan sesuai dengan kebutuhan. Hasil dari penelitian ini adalah membuat sistem pengelolaan aplikasi pengaduan masyarakat untuk admin yang berbentuk web aplikasi untuk menampung hasil dari pengaduan dari masyarakat yang menggunakan aplikasi mobile, dengan harapan pihak kelurahan dapat mendengarkan setiap keluhan yang masuk dari masyarakat melewati aplikasi ini dan dapat direspon dengan baik dan ditindak lanjuti hasil dari pelaporan masyarakat.
\end{abstract}

Kata kunci: Extreme Programming (XP), Aplikasi Pengaduan Masyarakat, Kelurahan.

\section{Pendahuluan}

Informasi merupakan hal yang sangat penting bagi setiap individu maupun instansi pemerintahan didalam mengambil keputusan. Semakin cepatnya arus informasi di dunia, maka setiap instansi pemerintahan saat ini diharapkan dapat menyampaikan setiap informasi yang mereka miliki dengan cepat dan tepat serta solusi atas problematika yang terjadi ditengah-tengah masyarakat.

Pada dasar permasalahannya pengaduan ini masih bersifat manual yang terjadi di masyarakat maka waktu yang digunakan pun tidak efisien. Masyarakat merasakan sulitnya untuk menyampaikan aspirasinya atau pengaduannya terhadap keresahan dilingkungannya kepada pihak instansi pemerintahaan. Pengaduan masyarakat merupakan suatu bentuk partisipasi untuk ikut berperan dalam membangun lingkungannya serta sebagai bentuk pengawasan terhadap kinerja instansi pemerintahan. Laporan maupun aspirasi masyarakat dapat dipergunakan sebagai bahan masukan untuk mengevaluasi kebijakan dan peraturan yang telah dibuat atau peraturan yang telah dilaksanakan dan untuk mengetahui masalah yang ada didalam masyarakat secara efektif, cepat dan up to date serta dapat langsung memberikan solusi dan jalan keluarnya.
Kelurahan Kukusan adalah sebuah kelurahan yang terletak di daerah Beji, Depok lebih tepatnya di Jawa Barat. Sebagai salah satu instansi pemerintahan terdekat dengan masyarakat, maka harus dapat memberikan kenyamanan kepada warganya dan dapat memberikan solusi dari berbagai permasalahan yang terjadi di masyarakat yang terdapat di wiliyah kerjanya secara efektif, cepat dan up to date.

Hasil dalam bentuk wawancara dengan pihak kelurahan mengenai permasalahan tentang pengaduan masyarakat yaitu dari bentuk pertanyaan "Apakah ada unit pelayanan pengaduan masyarakat dalam struktur organisasi penyelenggara pelayanan ?" untuk bentuk khusus dalam pelayanan pengaduan masyarakat memang belum ada, tetapi biasanya mereka datang langsung dengan pihak RT atau RW, pertanyaan selanjutnya "Apakah pelayanan pengaduan masyarakat dapat dijadikan sebagai upaya peningkatan kualitas pelayanan dan perbaikan kinerja ?" pengaduan masyarakat tentunya sebagai bahan koreksi untuk pihak kelurahan dalam memperbaiki untuk bisa lebih baik lagi kedepannya dalam memajukan lingkungan bagi masyarakat, pertanyaan selanjutnya "Bagaimana keberadaan dan eksistensi unit atau lembaga pelayanan pengaduan yang telah berjalan dalam penyelenggaraan pelayananan publik ?" sejauh ini memang masih manual 
atau datang langsung dan bisa melalui kotak yang sudah disiapkan. (Hasil wawancara penelitian terlampir pada lampiran E)

Diharapkan dengan adanya fasilitas perancangan aplikasi pengaduan masyarakat ini dapat menimbulkan hubungan yang baik dari masyarakat dan pemerintahan untuk memajukan lingkungan sekitar seefeektif dan seefisien mungkin.

Oleh karena itu untuk membantu memudahkan kebutuhan masyarakat dalam melakukan pengaduan kepada pemerintahaan setempat, maka berdasarkan pada masalah diatas, maka penulis mengusulkan dalam penyusunan skripsi ini penulis memilih judul "Perancangan Aplikasi Pengaduan Masyarakat Terhadap Lingkungan Di Tingkat Kelurahan".

\section{$2 \quad$ Landasan Teori}

\subsection{Pengertian Lingkungan}

Lingkungan adalah segala sesuatu baik fisik, biologis maupun sosial yang berada disekitar manusia serta pengaruh-pengaruh luar yang mempengaruhi kehidupan dan perkembangan manusia. Ada tiga jenis lingkungan antara lain (Lenihhan \& Fletter, 2000)]:

a. Lingkungan Fisik adalah segala sesuatu yang berada disekitar manusia yang tidak bernyawa. Misalnya air, suhu, rumah dan benda mati lainnya.

b. Lingkungan Biologis adalah segala sesuatu yang bersifat hidup seperti tumbuh- tumbuhan, hewan serta mikroorganisme.

c. Lingkungan Sosial segala tindakan yang mengatur kehidupan manusia dan usaha- usahanya untuk mempertahankan kehidupan seperti pendidikan pada tiap individu, rasa tanggung jawab, pengetahuan keluarga, jenis pekerjaan, jumlah penghuni dan keaadaan ekonomi.

\subsection{Android}

Android merupakan sebuah sistem operasi telepon seluler dan komputer tablet layar sentuh (touch screen) yang berbasis Linux. Namun seiring perkembangannya, Android berubah menjadi platform yang begitu cepat dalam melakukan inovasi. Hal ini tidak lepas dari pengembang utama dibelakangnya, yaitu Google. Google lah yang mengakusisi Android, kemudia membuatkan sebuah platform.

Platform adalah teknologi yang digunakan sebagai dasar atas nama aplikasi yang lainnya, proses atau teknologi yang dibangun. Pada komputer pribadi, platform adalah peragkat lunak dasar atau komputer itu sendiri dan perangkat lunak atau sistem operasi yang mana perangkat lunak lainnya bisa berjalan.Android adalah aplikasi yang bebas untuk dikembangkan. Tidak ada lisensi atau biaya royalty untuk dikemangkan pada platform android ini. Tidak ada biaya keanggotaan yang diperlukan. Tidak ada biaya pengujian, bahkan tidak ada kontrak yang diperlukan. Aplikasi untuk android dapat didistribusikan dan diperdagangkan dalam bentuk apapun.[3]

\subsection{Software Development Kit (SDK)}

Android SDK adalah tools API (Application Programming Interface) yang diperlukan untuk memulai mengembangkan aplikasi pada platform Android menggunakan bahasa pemrograman Java. Beberapa fitur Android yanng penting adalah sebagai berikut [4] :

a. Framework aplikasi yang mendukung penggantian komponen dan reusabel.

b. Integrated browser berdasarkan engine open source webkit.

c. Dukungan untuk audio, video dan gambar.

d. Kamera, GPS, kompas dan accelerometer.

\section{Metodologi Penelitian}

\subsection{Diagram Alur Penelitian}

Metodologi alur penelitian yang penulis gunakan seperti dibawah ini:

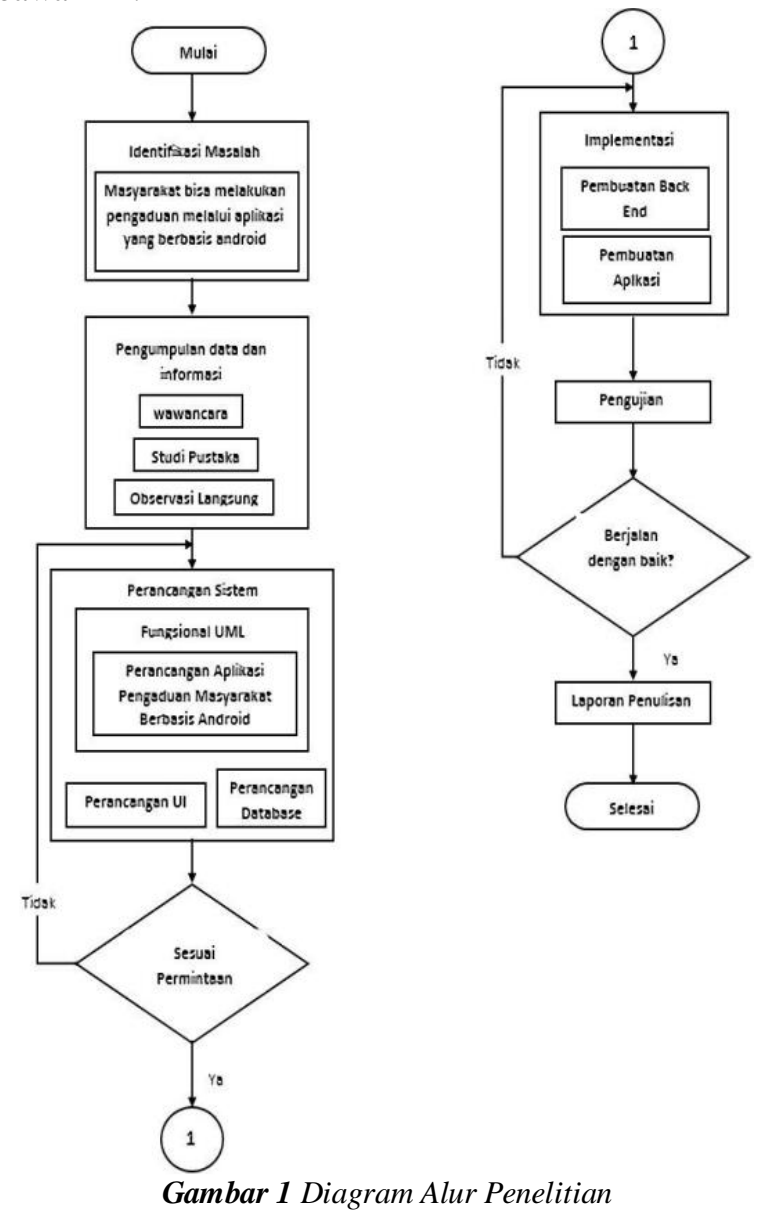

3.2. Metode Pengembangan

Metodologi pembuatan dan perancangan perangkat lunak yang digunakan yaitu Agile Process dengan pendekatan Extreme Programming (XP). Extreme Programming berfokus pada coding sebagai aktivitas utama disemua tahap pada siklus pengembangan yang lebih responsif terhadap kebutuhan customer ("agile") dibandingkan dengan metode metode tradisional. Selain itu Extreme Programming meliputi seluruh area pengembangan perangkat lunak, Adapun tahapan-tahapan yang dilakukan 
dalam metode Extreme Programming yaitu Planning, Design, Coding, dan Testing. [5]

Penjelasan lebih terperinci untuk tahapan- tahapan dari Extreme Programming adalah sebagai berikut :

a. Planning, merupakan deskripsi fitur-fitur fungsional yang dibutuhkan untuk membangun aplikasi mobile.

b. Design, akan menterjemahkan syarat kebutuhan ke sebuah perancangan perangkat lunak dengan mengatur class pada konsep beroerintasi objek.

c. Coding, menerjemahkan dari tahapan design ke dalam bahasa yang bisa dikenali oleh komputer.

d. Testing, merupakan pengujian kebenaran logic dan fungsional pada aplikasi mobile.

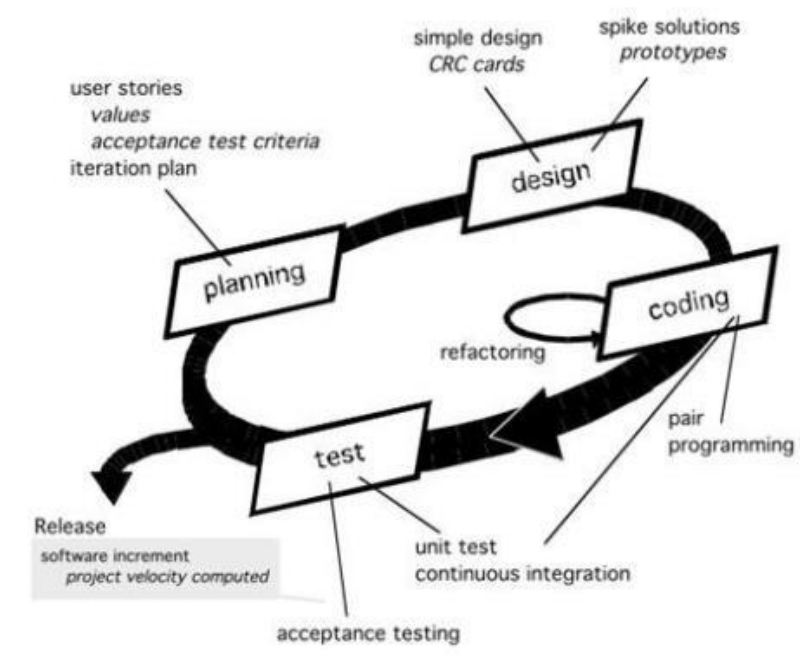

Gambar 2 Extreme Programming (XP)

\section{Hasil dan Pembahasan}

\subsection{Usecase Diagram}

Perancangan usecase diagram ini mendeskripsikan fungsionalitas sistem apa saja yang harus dilakukan sesuai dengan apa yang diinginkan oleh external aktor. Aktor yang berinteraksi dengan sistem dapat berupa user atau sistem lain. Penulis menspesifikasikan terdapat 3 aktor, dimana aktoraktor tersebut dapat mengoperasikan fungsi-fungsi yang diberikan oleh sistem dalam bentuk teks. Aktor pengguna dapat mengoperasikan fungsi yang pertama-tama yaitu mengisikan form login, melihat informasi yang up to date, dan melakukan pengaduan, kemudian didalam pengaduan terdapat field-field untuk diisi yaitu judul aduan, alamat, deskripsi pengaduan dan foto. Aktor admin yaitu mengelola keseluruhan sistem yang ada di web.

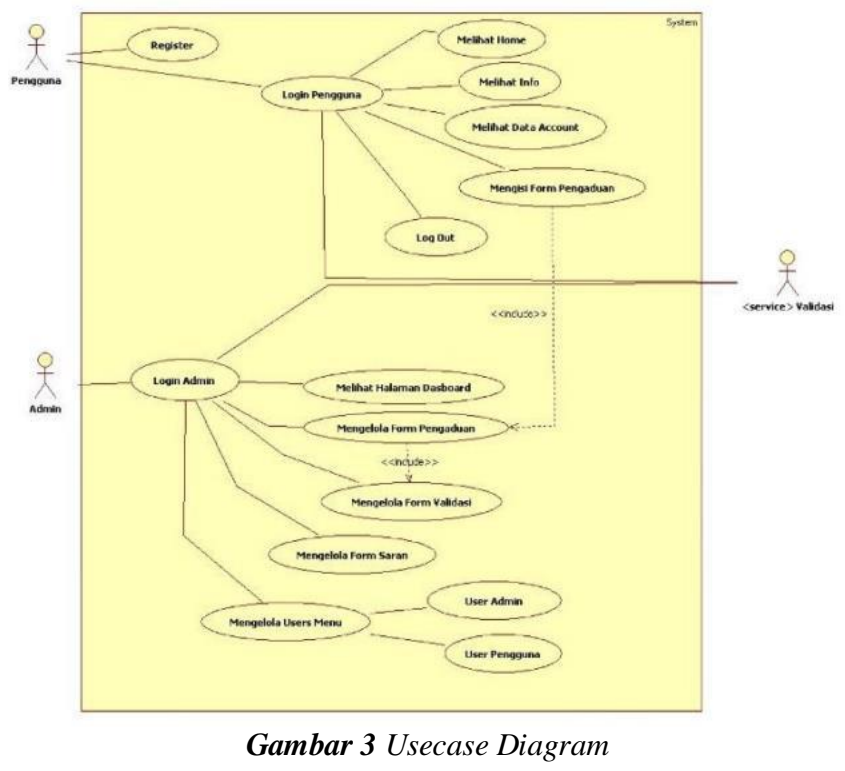

4.2. Class Diagram

Merupakan hubungan antar kelas dan penjelasan detail tiaptiap kelas didalam model desain dari suatu sistem, juga memperlihatkan aturan-aturan dan tanggung jawab entitas yang menentukan perilaku sistem. Class diagram secara khas meliputi: Kelas (Class), Relasi Assosiations, Generalitation dan Aggregation, Attribut (Attributes), Operasi (Operation/Method), dan visibility, tingkan akses objek eskternal kepada suatu operasi atau attribut. Penulis memodelkan terdapat 15 class sesuai usecase. Berikut ini adalah gambaran class diagram aplikasi pengaduan masyarakat.

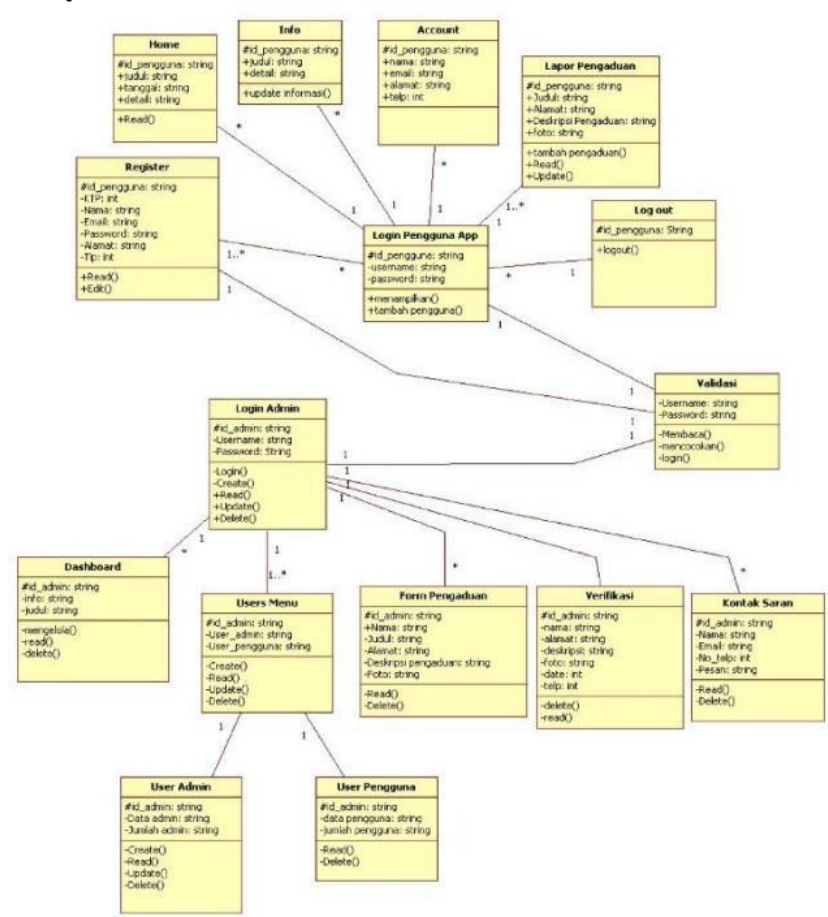

Gambar 4 Class Diagram 


\subsection{Rancangan Mockup}

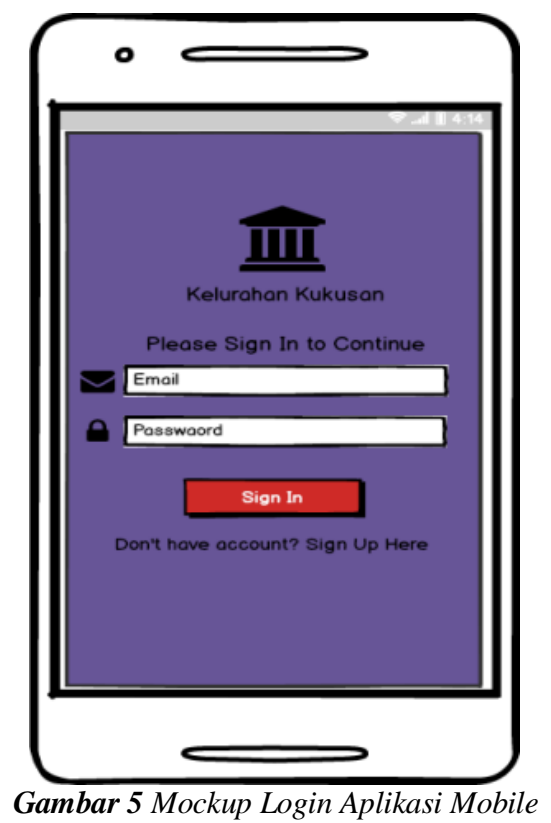

Pada gambar 5 adalah menunjukan tampilan mockup halaman login pengguna yang berisikan inputan username dan password.

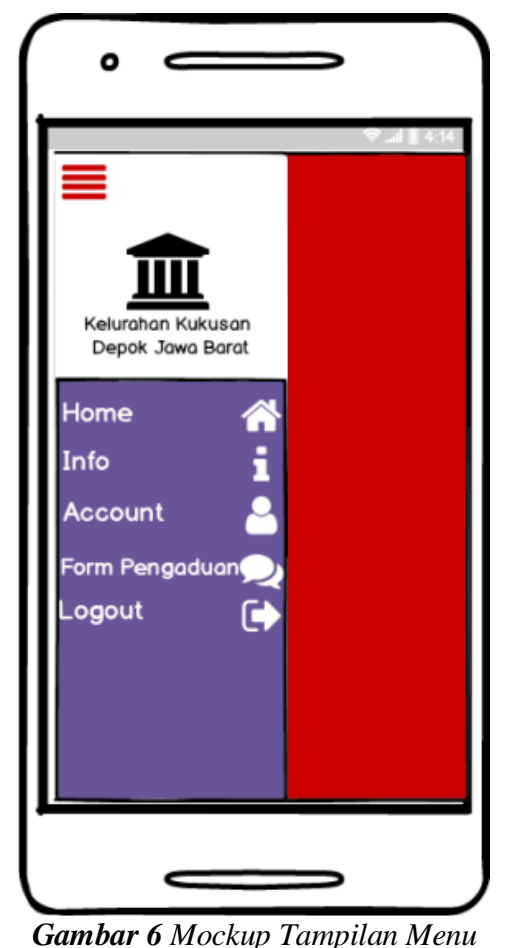

Pada gambar 6 adalah menunjukan tampilan mockup halaman tampilan menu pengguna aplikasi yang berisikan menu home, info, account, form pengaduan dan logout.

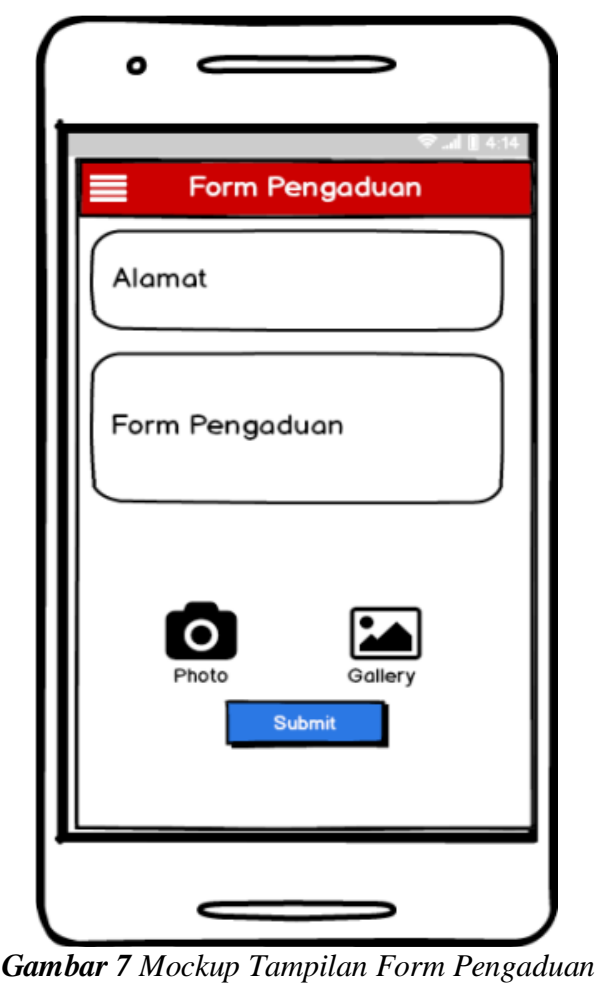

Pada gambar 7 adalah menunjukan tampilan mockup halaman menu form pengaduan pengguna aplikasi yang berisikan form inputan dari, lokasi alamat dan deskripsi pengaduan beserta bukti lampiran foto bisa melalui foto langsung kejadian atau memilih dari galeri yang sudah tersimpan di dalam memori handphone.

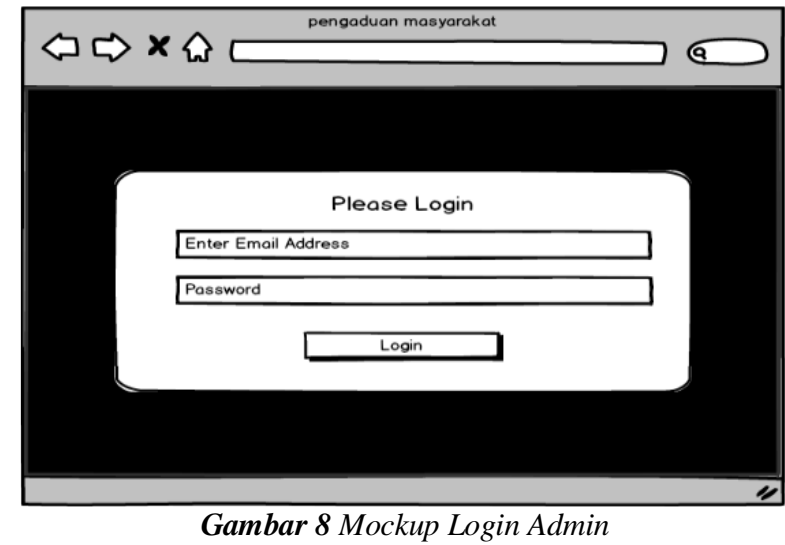

Pada gambar 8 adalah menunjukan tampilan mockup halaman login admin yang berisikan inputan username dan password. 


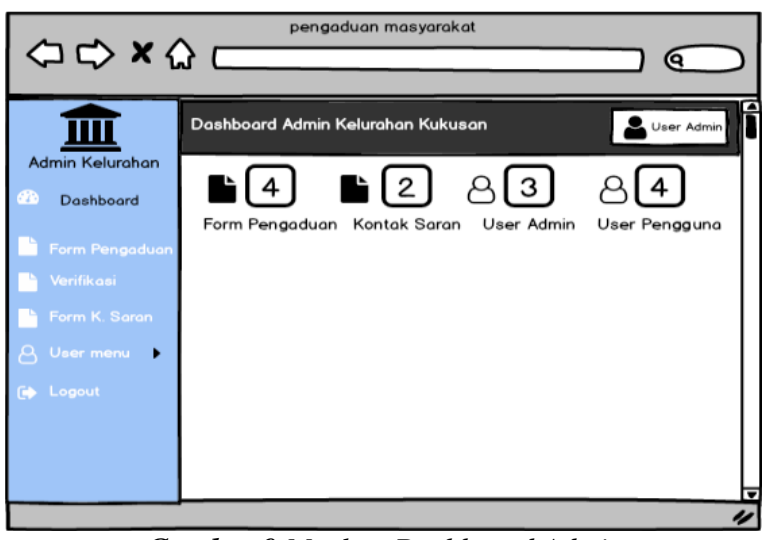

Gambar 9 Mockup Dashboard Admin

Pada gambar 9 adalah menunjukan tampilan mockup halaman Dashboard admin, yang berisikan icon-icon yang mewakili dari setiap menu yang terdapat di web aplikasi.

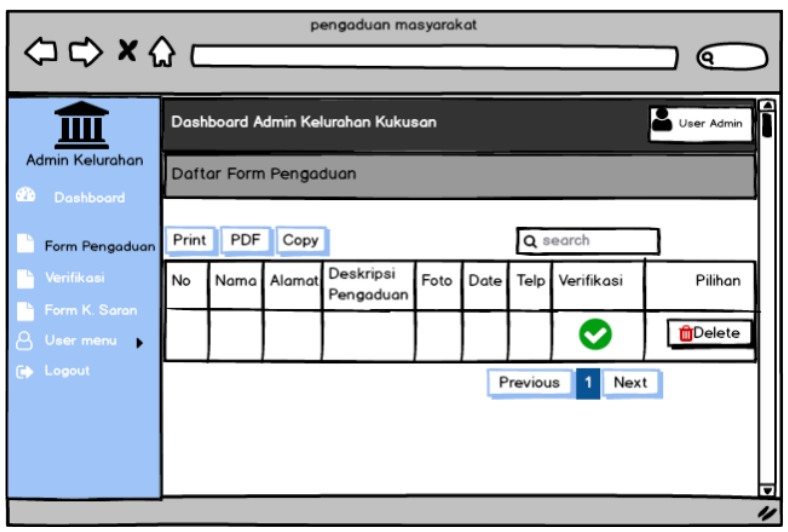

Gambar 10 Mockup Form Pengaduan

Pada gambar 10 adalah menunjukan tampilan mockup halaman form pengaduan, yang berisikan data tabel laporan hasil dari inputan user pengguna dari mobile aplikasi, terdapat shorcut print, PDF, Copy untuk export data, dan ada tombol delete untuk menghapus data yang memiliki value tidak valid.

\subsection{Implementasi Antar Muka}

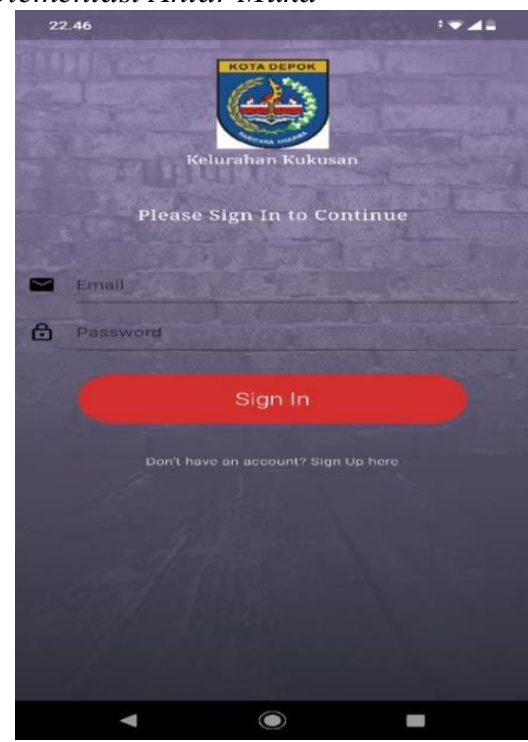

Gambar 11 Tampilan Login Pengguna pengguna diharapkan untuk melakukan login dengan mengisi e-mail dan password pada form yang sudah disediakan hasil dari e-mail dan password yang telah diisi halaman register sebelumnya, setelah semua form terisi maka langkah selanjutnya yaitu menekan tombol sign in untuk melangkah ke halaman selanjutnya.

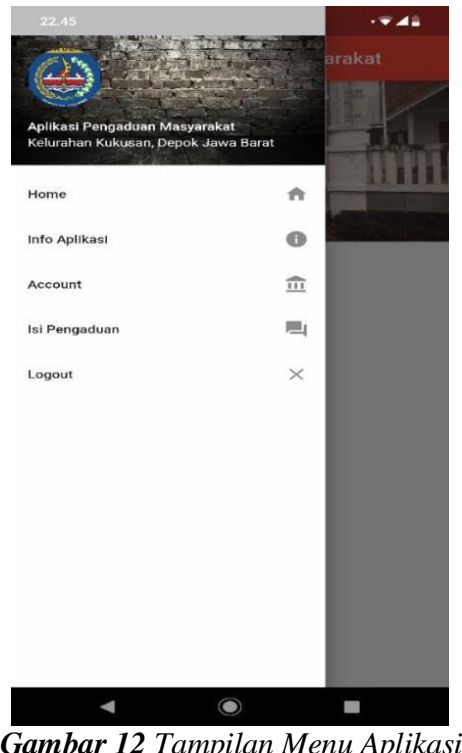

halaman tampilan menu ini dengan mengklik side bar yang ada dipojok kiri atas yang ada pada aplikasi ini, menu yang terdapat diaplikasi ini meliputi home, info aplikasi, account, isi pengaduan dan log out.

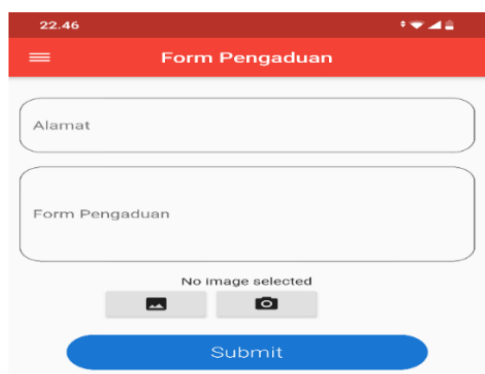

\section{Gambar 13 Tampilan Menu Form Pengaduan}

Tampilan form pengaduan ini adalah tampilan dari menu aplikasi yang dipakai untuk melaporkan suatu pengaduan terhadap kejadian yang ada dilingkungan, pembuatan aplikasi berdasarkan dari metode pengembangan agile process dengan pendekatan extreme programming melalui 4 tahapan yaitu planning, design, coding dan testing, diharapkan dengan adanya pengaduan masyarakat ini dapat merespon dan tersampiakan secara cepat, efektif di pemerintahan terkait. 


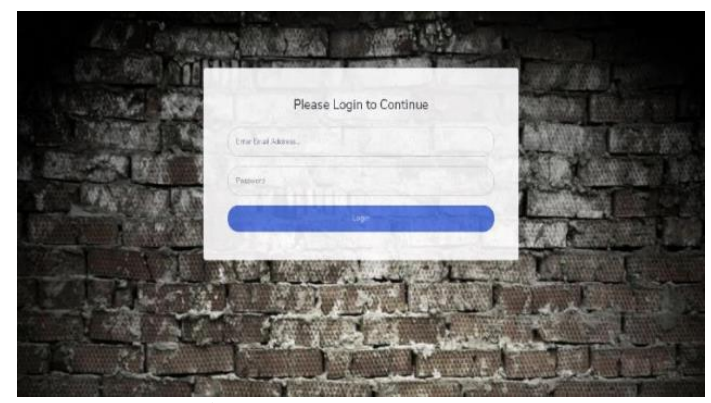

Gambar 14 Tampilan Login Admin

Tampilan halaman admin ini merupakan tampilan awal jika admin tersebut belum login. Dimana pada halaman ini admin yang sudah terdaftar di database harus melakukan proses login, untuk dapat mengakses dan mengelola data pada halaman admin.

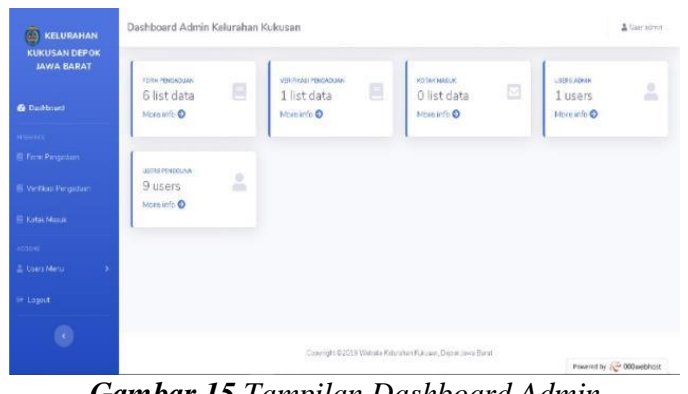

Gambar 15 Tampilan Dashboard Admin

Setelah admin tersebut benar dalam memasukan username dan password maka akan secara otomatis diarahkan ke tampilan dashboard administrator.

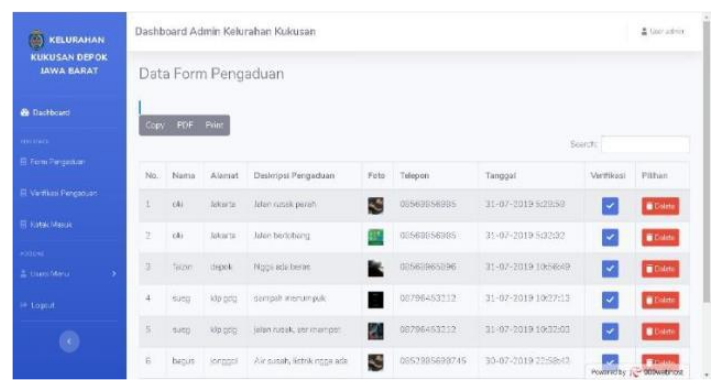

Gambar 16 Tampilan Form Pengaduan

Pada halaman form pengaduan, dapat melihat pelaporan atau pengaduan dari masyarakat tentang keluhan yang dilaporkan melalui aplikasi pengaduan masyarakat yang dipakai, pembuatan aplikasi berdasarkan dari metode pengembangan extreme programming melalui 4 tahapan yaitu planning, design, coding dan testing.

\subsection{Chart Kuesioner Pengujia Aplikasi}

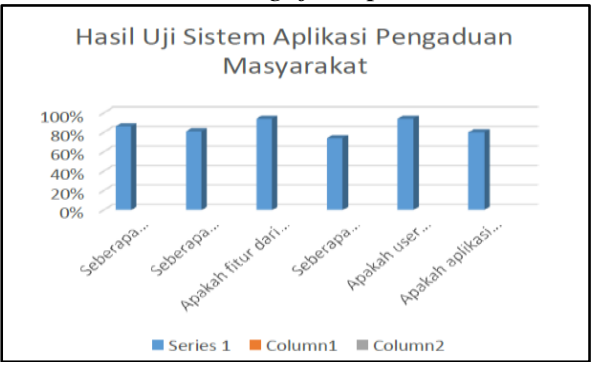

Gambar 17 Chart Hasil KuesionerPengujian Aplikasi

\section{Kesimpulan}

Kesimpulan dari penelitian skripsi yang berjudul "Model Aplikasi Pengaduan Masyarakat Terhadap Lingkungan Di Tingkat Kelurahan, adalah sebagai berikut:

a. Dari hasil kuesioner uji coba aplikasi yang mengandung nilai aspek usability yang mencakup lima komponen yaitu learnability, efficiency, memorability, errors, satisfaction. Mendapatkan rata-rata persentase $84 \%$. Berarti dapat diasumsikan aplikasi ini sudah dapat berjalan dengan sangat baik, dan aplikasi pengaduan masyarakat sudah dapat digunakan untuk melakukan pelaporan terhadap lingkungan yang terdapat keresahan dari masyarakat dan ditujukan untuk pemerintahan untuk mengambil tindakan atas kejadian yang sudah dilaporkan. Pengujian UAT (User Acceptance Test) untuk web aplikasi sudah dilakukan kepada admin yang bersangkutan yaitu pihak dari kelurahan menggunakan metode black box testing untuk pengujiannya dan sukses.

b. Membuat sistem pengelolaan aplikasi pengaduan masyarakat untuk admin yang berbasis web aplikasi untuk menampung hasil dari pengaduan dari masyarakat yang menggunakan aplikasi mobile, sistem ini dibuat untuk memudahkan masyarakat dalam menyampaikan keluhan yang ada di lingkungan kepada pihak pemerintahan terdekat yaitu kelurahan, dengan harapan pihak kelurahan dapat mendengarkan setiap keluhan yang masuk dari masyarakat masuk melewati aplikasi ini dan dapat ditanggapi dan direspon dengan baik dan ditindak lanjuti hasil dari pelaporan masyarakat.

\section{Kepustakaan}

[1] BAPPENAS, "Manajemen Pengaduan Masyarakat dalam Pelayanan Publik," Lap. Kaji., 2010.

[2] Witra Apdhi Yohanitas and Teguh Henry Prayitno, "Pengelolaan Pengaduan Masyarakat Kota Bekasi," J. Borneo Adm. , vol. 10, no. 3, pp. 328-352, 2014

[3] U. S. Utara, U. S. Utara, and U. S. Utara, "Perancangan Aplikasi Pengaduan Masyarakat di Kecamatan Secanggang Menggunakan Android," 2018.

[4] A. Juansyah, "Pembangunan Aplikasi Stok Tek Barang Gudang Berbasis Android Jurnal Ilmiah Komputer dan Informatika ( KOMPUT A )," J. Ilm. Komput. dan Inform., vol. 1, no. 1, pp. 1$8,2015$.

[5] A. Jumardi and A. Solichin, "Prototipe Aplikasi Layanan Pengaduan Masyarakat Berbasis Android Dan Web Service," J. Telemat. MKOM, vol. 8, no. 1, pp. 81-88, 2016.

[6] I. Safi, "RANCANGAN APLIKASI LAYANAN PENGADUAN MASYARAKAT DENGAN METODE EXTREME PROGRAMMING ( Studi kasus : Kabupaten Ngawi ),” no. 32, pp. 7-12, 2017.

[7] A. Y., I. A. Prabowo, and A. Normassari, "(Alpukat) Aplikasi Pengaduan Masyarakat Untuk Melaporkan Kejadian Pungutan Liar Di Kabupaten Kudus Berbasis Android," Simetris J. Tek. Mesin, Elektro dan Ilmu Komput., vol. 8, no. 2, p. 399, 2017. 